\title{
ENERGY EXGHANGE AT A GLAGIER SURFACE: AN ALTERNATIVE TO AERODYNAMIC METHODS OF MEASUREMENT
}

\author{
By A. C. Wager and A. W. Jamieson* \\ (British Antarctic Survey, Madingley Road, Cambridge $\mathrm{CB}_{3}$ oET, England)
}

\begin{abstract}
Analysis of wind-speed measurements made over a six-month period on an Antarctic glacier showed that conditions near the surface were dominated by gravity winds flowing downhill. In such conditions there is no satisfactory method of calculating the amount of energy exchanged between the glacier and the atmosphere. It is also difficult to extrapolate satisfactorily energy changes measured at a single point to the whole glacier. Moreover the loss of five days' meteorological records may cause an error as large as the total change in energy content of the glacier during a year. In view of these difficulties it is more fruitful to measure the changes in energy content of the glacier directly. This can be done by accurate measurements of ice temperature and density near the surface. By defining the total energy content of a glacier as the heat required to melt it, fractional changes in the energy content and mass occurring over a year are equal and indicate the probable lifetime of the glacier. Estimates based on data from an Antarctic glacier suggest that the long-term change of energy of the glacier $\left(\approx 1.5 \mathrm{~W} / \mathrm{m}^{2}\right)$ could be measured with an accuracy of $10 \%$ within a year.
\end{abstract}

RÉsumÉ. Échanges d'energie à la surface d'un glacier: une alternative aux méthodes aérodynamiques de mesure. L'analyse des mesures de vitesse de vent réalisées pendant une période de six mois sur un glacier Antarctique a montré que les conditions près de la surface étaient dominées par les vents de gravité s'écoulant de haut en bas. Dans de telles conditions, il n'y a pas de méthode satisfaisante pour calculer la quantité d'énergie échangée entre le glacier et l'atmosphère. Il est également difficile d'extrapoler sur toute l'étendue d'un glacier de manière satisfaisante les échanges d'énergie mesurés en un point particulier. Bien plus, la perte de cinq jours de données météorologiques peut entraîner une erreur aussi grande que le bilan énergétique total du glacier pendant un an. En raison de ces difficultés, il est plus fructueux de mesurer directement le bilan énergétique du glacier. Ceci peut se faire par des mesures précises de température de la glace et de densité près de la surface. En définissant le contenu énergétique total d'un glacier comme la chaleur qu'il faudrait lui fournir pour le faire fondre, les changements partiels du contenu énergétique et de masse survenant au cours d'une année sont égaux et donnent une idée de la durée de vie probable du glacier. Des estimations basées sur des données recueillies sur un glacier d'Antarctique font penser que le bilan énergétique à long terme d'un glacier (de l'ordre de $1,5 \mathrm{~W} / \mathrm{m}^{2}$ ) pourrait être mesuré avec une précision de $10 \%$ en une année.

Zusammenfassung. Energieaustausch an einer Gletscher-Oberfläche: Eine Alternative zu aerodynamischen Messmethoden. Eine Analyse von Messungen der Windgeschwindigkeit während einer Periode von 6 Monaten auf einem antarktischen Gletscher zeigt, dass die Verhältnisse an der Oberfläche durch abwärts wehende Schwerkraftwinde beherrscht sind. Unter solchen Bedingungen gibt es keine befriedigende Methode zur Berechnung der zwischen dem Gletscher und der Atmosphäre ausgetauschten Energie. Ebenso ist es schwierig, die an einem Punkt gemessenen Energieumsätze auf den ganzen Gletscher zufriedenstellend zu extrapolieren. Ausserdem kann der Verlust der meteorologischen Aufzeichnungen über 5 Tage einen Fehler verursachen, dessen Grössenordnung der Änderung des Energiegehaltes des Gletschers während eines ganzen Jahres entspricht. Im Hinblick auf diese Schwierigkeiten ist es vernünftiger, die Änderungen im Energiegehalt des Gletschers direkt zu messen. Dies kann durch genaue Messung der Eistemperatur und -dichte nahe der Oberfläche geschehen. Definiert man den gesamten Energiegehalt eines Gletschers als die Wärme, die zu seinem Abschmelzen nötig ist, so entsprechen sich teilweise Änderungen im Energiegehalt und in der Masse im Verlauf eines Jahres und geben einen Hinweis auf die wahrscheinliche Lebensdauer des Gletschers. Abschätzungen, die auf Daten von einem antarktischem Gletscher beruhen, lassen erwarten, dass langzeitige Änderungen der Energie $\left(1,5 \mathrm{~W} / \mathrm{cm}^{2}\right)$ des Gletschers mit einer Genauigkeit von $1^{\circ}$ 。 innerhalb eines Jahres gemessen werden können.

\section{INTRODUCTION}

One of the agreed objectives of the International Hydrological Decade 1965-74 was to determine the ice, water and energy balances of glaciers in many parts of the world (UNESCO/IASH, r970, r973).

The exchanges of energy and mass between a glacier and its surroundings are related as follows:

* Present address: $3^{8}$ Kincorth Crescent, Aberdeen, Scotland. 
Conservation of energy implies that the sources of energy available to a glacier are equal to the resulting changes in the energy of the glacier, i.e.

$$
F_{\mathrm{r}}+F_{\mathrm{c}}+F_{\mathrm{l}}+F_{\mathrm{g}}=F_{\mathrm{f}}+F_{\mathrm{t}}
$$

where $F_{\mathrm{r}}$ is the radiative heat flux, $F_{\mathrm{c}}$ the sensible heat flux, $F_{1}$ the latent heat flux from condensation and evaporation, $F_{\mathrm{g}}$ is a small amount of energy derived from geothermal heat, bottom friction and internal deformation, $F_{\mathrm{f}}$ is the change in energy content of the glacier due to latent heat associated with changes in the mass of snow and ice and $F_{t}$ the change in energy content of the glacier due to changes in temperature of the snow/ice mass.

Conservation of mass of ice implies that

$$
I_{\mathrm{p}}+I_{\mathrm{l}}+I_{\mathrm{r}}+I_{\mathrm{f}}=I_{\mathrm{m}}
$$

where $I_{\mathrm{p}}$ is the precipitation in the solid phase, $I_{1}$ the condensation/evaporation of ice, $I_{\mathrm{r}}$ the change of mass of ice and snow due to calving, snow-drift, avalanches, etc., $I_{\mathrm{f}}$ the change in mass of ice due to ice/water phase changes, and $I_{\mathrm{m}}$ the change in total ice mass.

Between 1969 and 1974 we studied Spartan Glacier in Alexander Island, the most southerly of an internationally selected chain of glaciers extending from Alaska through the Americas to the Antarctic Peninsula. We measured wind speed, temperature and humidity at several levels (Jamieson and Wager, in press) and have analysed data covering the period from September 1973 to January 1974. Measurements of wind speed indicated that conditions near the glacier surface were dominated by gravity winds flowing down the glacier. In such circumstances the method developed by Deacon (r949) to calculate sensible and latent heat fluxes $\left(F_{\mathrm{c}}\right.$ and $F_{1}$ in Equation (I)) could not be used. Holmgren (I97I), who studied these conditions in great detail, was also unable to derive a satisfactory theoretical treatment. A further difficulty with the aerodynamic method of estimating energy changes over the glacier was that measurements could only be made at a single point because of the work involved. It was very difficult to extrapolate these measurements satisfactorily to the whole glacier because meteorological conditions were affected by altitude and topography.

Yet another drawback to the aerodynamic method of obtaining the annual energy change was that radiative, sensible and latent heat fluxes had to be measured continuously for the whole year. These quantities had first to be measured, then extrapolated over the glacier, and finally summed for the whole year. Estimates made at Spartan Glacier showed that the mean rate of energy exchange was $1.5 \mathrm{~W} / \mathrm{m}^{2}$. The energy gain in summer was about I $00 \mathrm{~W} / \mathrm{m}^{2}$, and the energy loss in winter was about $5^{0} \mathrm{~W} / \mathrm{m}^{2}$. The loss of five days' records in summer or ten days' records in winter could have caused an error of the same size as the total change in energy content of the glacier during the whole year.

Although aerodynamic methods can reveal the relative energy contributions from different atmospheric sources, we do not believe that they can be used to determine accurately the total energy change of an entire glacier. Radiation measurements can be made to an acceptable accuracy, although in polar regions much of the incoming radiation is reflected and the energy supplied by turbulent transfer is generally of the same order of magnitude as the net radiation (Liljequist, I957, p. 292; Dalrymple and others, 1966, p. 55). For these reasons alternative methods should be considered in order to determine accurately changes in the total energy content of a glacier.

The energy content of a glacier $E$ may usefully be defined as the total energy required to melt it.

$$
E=\iiint_{V}(c \theta-L) \rho \mathrm{d} V
$$

where $c$ is the specific heat capacity of ice, $\theta$ is the Celsius ice temperature, $L$ is the latent heat of fusion of ice, $\rho$ is the density of ice, and $V$ is the volume of the glacier. 
The corresponding definition of the total mass of the glacier $M$ is

$$
M=\iiint_{V} \rho \mathrm{d} I^{*} .
$$

Because the energy $F_{\mathrm{r}}+F_{\mathrm{c}}+F_{1}+F_{\mathrm{g}}$ (Equation (I)) must be supplied from sources external to the glacier, it is logical to treat the energy content $E$ as negative. It also follows from the definition of $E$ that the heat content of water at $0^{\circ} \mathrm{C}$ is zero.

From Equation (I), $F_{\mathrm{t}}+F_{\mathrm{f}}(=\Delta E)$ is the change in energy content of the glacier. The predicted lifetime of the glacier $\lambda$ is

$$
\lambda=\frac{E}{\Delta E}=\frac{M}{\Delta M}
$$

where $\Delta E$ and $\Delta . M$ are the measured changes in energy and mass in one year and $E$ and $M$ are the total energy and mass of the glacier. If the glacier is decreasing then $\lambda$ is the length of time until it vanishes. If the glacier has been increasing continuously, then it is the length of time for which it has been in existence.

\section{DiRECT DETERMINATION OF ENERGY AND MASS CHANGES}

\section{Theoretical considerations}

Consider a valley glacier (Fig. 1). The line $z=z_{0}$ represents a surface below which there is very little heat conducted from the atmosphere during the study period. The energy content of the volume below this surface is changed slightly by deformation, by friction on the bed, by geothermal heat and by the heat $\delta$ required to melt the small volume lost at the snout.

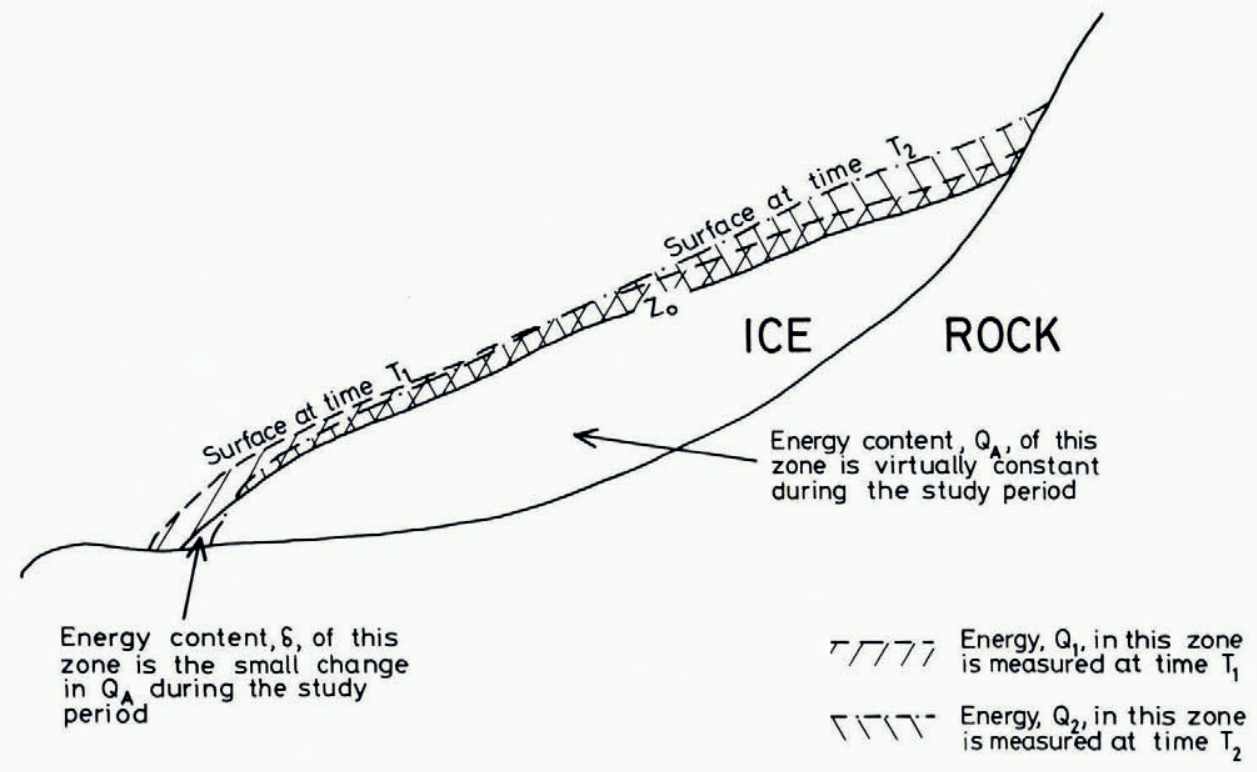

Fig. 1. Longitudinal section of a valley glacier showing zones with their associated energy content. 
We use the following notation:

$Q$ measured heat content of the volume between the surface $z=z_{0}$ and the glacier surface;

$\delta$ heat content of the volume of the glacier below the surface $z=z_{0}$ which is lost by melting at the snout;

$D$ energy supplied to the glacier by internal deformation (negligible near the surface);

$R$ energy supplied by friction at the bed of the glacier;

$G$ energy supplied as geothermal heat.

At time $T_{\mathrm{I}}$ the heat content of the glacier is $Q_{\mathrm{A}}+Q_{\mathrm{I}}$ where $Q_{\mathrm{A}}$ is the heat content of the volume below the surface $z=z_{0}$ and $Q_{1}$ is measured at time $T_{1}$. At time $T_{2}$ the heat content of the glacier is

$$
Q_{\mathrm{A}}+Q_{2}+\delta+D+R+G
$$

where $Q_{2}$ is measured at time $T_{2}$.

The change in heat content of the entire glacier is therefore

$$
\Delta E=Q_{2}-Q_{1}+\delta+D+R+G \text {. }
$$

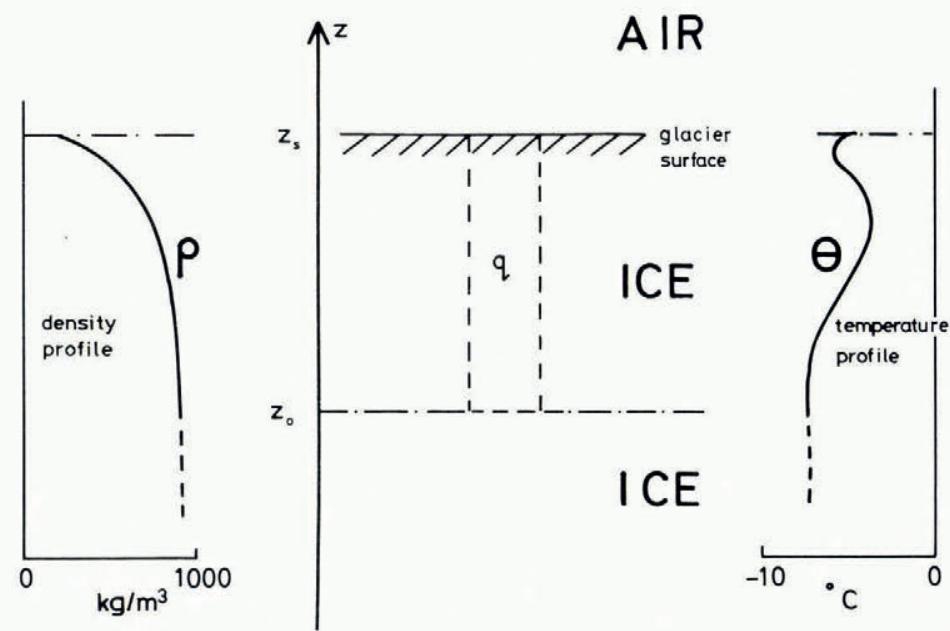

Fig. 2. Vertical section near the glacier surface. $q$ is the energy content of the prism bounded by pecked lines. It is calculated from the profiles of $\rho$ and $\theta$.

Consider a prism extending through the glacier (Fig. 2). The heat required to melt the ice in the prism down to the $z=z_{0}$ surface is

$$
q=c \int_{z_{0}}^{z_{\mathrm{s}}} \theta \rho \mathrm{d} z-L \int_{z_{0}}^{z_{\mathrm{s}}} \rho \mathrm{d} z
$$

The total heat content $Q$ of the volume above the surface $z=z_{0}$ is the surface integral of $q$ over the glacier.

$$
Q=\iint_{A} q \mathrm{~d} A
$$

where $A$ is the area of the glacier. 
The change of heat content of the surface layers $Q_{2}-Q_{1}$ is given by

$$
\Delta Q=\left(Q_{2}-Q_{\mathrm{I}}\right)=\iint_{A} \Delta q \mathrm{~d} A
$$

where

$$
\Delta q=q_{2}-q_{1}
$$

Similarly the change in mass of the glacier is

$$
I_{\mathrm{m}}=M_{2}-M_{\mathrm{I}}+\Gamma
$$

where $M_{1}$ and $M_{2}$ are the masses of ice above the surface $z=z_{0}$ at times $T_{1}$ and $T_{2}, \Gamma$ is the aggregate of mass changes below the surface $z=z_{0}$ caused by bottom melting, by ablation at the snout, and by freezing of water in crevasses.

$$
\Delta M=\left(M_{2}-M_{1}\right)=\iint_{A} \Delta m \mathrm{~d} A
$$

where

$$
\Delta m=m_{2}-m_{\mathrm{I}}
$$

and

$$
m=\int_{z_{0}}^{z_{\sharp}} \rho \mathrm{d} z
$$

\section{Location of the $z_{0}$ surface}

Measurements are referred to a $z_{0}$ surface, which must be used again for subsequent measurements. The $z_{0}$ surface should be chosen below the level at which there is significant heat flow even at the end of the study period. It may be chosen at a shallower depth in the accumulation area than in the ablation area.

Since the $z_{0}$ surface can be relocated only by reference to stakes drilled into the glacier, it is essential that the stakes remain in place for the entire study period. This may prevent the method being used on glaciers with extensive ablation areas where the stakes cannot be planted deeply enough to remain in place through several ablation seasons. In the accumulation area, the settling of stakes relative to the $z_{0}$ surface must be taken into account.

\section{Practical considerations}

In principle $\rho$ and $\theta$ can be measured at any point in the glacier. It is sufficient to consider the volume above the $z_{0}$ surface because $Q_{\mathrm{A}}$ is almost constant.

To perform the surface integral for $Q$ we need values of $\Delta q$ over the glacier surface. In practice, we must interpolate between sampled points. The required density of points depends on the complexity of the accumulation pattern. We must determine the temperature and density profiles down to the $z_{0}$ surface at each point. The integral for $\Delta q$ can then be calculated numerically.

\section{Temperature profiles}

The most reliable way to maintain a datum for ice temperatures is to bond sensors to a stake made of an insulating material drilled into the $z_{0}$ surface. The choice between chromel/ constantan thermocouples and platinum resistance thermometers depends on cost, sensitivity, stability, and ease of measurement. 


\section{Density profiles}

Densities obtained at Spartan Glacier by weighing blocks of snow were not sufficiently precise. The blocks crumbled easily because they contained a large amount of superimposed ice. Even on glaciers where the block method is more accurate, gamma-ray transmission measurements (Smith and others, 1965) would be preferable in that they can determine the densities of a $\mathrm{I} \mathrm{cm}$ layer to an accuracy of $\mathrm{I} \%$.

\section{Evaluation of heat content at sample points}

We can now obtain the value of $\Delta q\left(=q_{2}-q_{1}\right)$ from Equation (5). Functional forms of $\rho$ and $\theta$ may be obtained by fitting suitable curves to the measured values. The integral may then be calculated by numerical methods.

\section{Evaluation of the surface integral}

To evaluate the surface integral of $\Delta q$ we use an array of equally spaced points covering the glacier. At each array point, we derive a value of $\Delta q$ by interpolation between the measured values.

The interpolation can be performed by computer programme (Dudnik, 197I). The surface integral becomes

$$
\frac{A}{7} \sum_{j=1}^{J} \Delta q_{j}
$$

where $A$ is the surface area of the glacier, $\Delta q_{j}$ is the $j$ th value of $\Delta q$ in the array of $\mathcal{J}$ points.

\section{Discussion}

\section{Energy changes at Spartan Glacier}

From Equation (4) the change in energy content of the glacier is

$$
\Delta E=\Delta Q+\delta+D+R+G .
$$

We have made estimates of the terms using data from Spartan Glacier. The estimates are expressed as energy input per unit time over the whole glacier divided by the surface area of the glacier.

(i) $\Delta E \approx 1.5 \mathrm{~W} / \mathrm{m}^{2}$ derived from the mass balance, assuming steady temperature conditions in the glacier.

(ii) $\delta \approx 0 . \mathrm{I} \mathrm{W} / \mathrm{m}^{2}$ derived from estimates of flow and thickness near the snout.

(iii) $(D+R) \approx 0.02 \mathrm{~W} / \mathrm{m}^{2}$. All the potential energy gained by the fall of the glacier appears as these two terms. [Mean velocity $25 \mathrm{~mm} / \mathrm{d}$ (Jamieson and Wager, in press); mean bottom slope $4^{\circ}$ (Wager, in press); total mass $700 \times 10^{9} \mathrm{~kg}$ (Jamieson and Wager, in press).]

(iv) $G \approx 0.04 \mathrm{~W} / \mathrm{m}^{2}$ (Runcorn, 1967$)$. Because $(D+R+G)$ must be small for any glacier, the change in energy content of the glacier becomes

$$
\Delta E \approx \Delta Q+\delta
$$

(v) $\Delta Q \approx 1.4 \mathrm{~W} / \mathrm{m}^{2}$ from the above equation. 
Accuracy of determination of $\Delta Q$

The integral for $\Delta q$ consists of two parts

$$
c \int_{i=1}^{*} \rho \theta \mathrm{d} z
$$

in which the smallest detectable energy change is about $10^{6} \mathrm{~J} / \mathrm{m}^{2}$. This is the result of a temperature change of $0.1 \mathrm{deg}$ at the surface. We assumed the $z_{0}$ surface to be $10 \mathrm{~m}$ deep.

$$
L \int_{z=1}^{\infty} \rho \mathrm{d} z
$$

and the smallest detectable energy change is again about $10^{6} \mathrm{~J} / \mathrm{m}^{2}$. This is the result of a I $\mathrm{cm}$ change in the surface level $z_{\mathrm{s}}$, assuming a density near the surface of $250 \mathrm{~kg} / \mathrm{m}^{3}$.

${ }_{10} 0^{6} \mathrm{~J} / \mathrm{m}^{2}$ would be transferred in $8 \mathrm{~d}$ at $1.5 \mathrm{~W} / \mathrm{m}^{2}$, the average energy input at Spartan Glacier. It should therefore be possible to measure the change in energy content per year to within $3 \%$ averaged over the glacier. Uncertainties in the surface integral increase this error. However, it is likely that $\Delta Q$ can be determined to within $10 \%$ in one year.

A series of measurements of $\Delta E(=\Delta Q+\delta)$ for, say, io years would establish the trend and the variation from year to year. Approximate values of $\Delta E$ at Spartan Glacier were calculated from the mass balance by assuming steady-state temperature conditions. The results

\begin{tabular}{|c|c|}
\hline Year & $\begin{array}{l}\text { Increase in total energy } \Delta E \\
\qquad \mathrm{~J} \times 10^{14}\end{array}$ \\
\hline 1970 & 5.0 \\
\hline 1971 & 5.6 \\
\hline 1972 & 7.8 \\
\hline I 973 & 4.6 \\
\hline
\end{tabular}
are shown in Table I.

\section{Free water}

Free water in the layers above the $z_{0}$ surface produces errors in both integrals in Equation (5). The specific heat capacity of water is twice that of ice and the heat content is, by our definition, zero. Therefore $q$ must be determined at times when there is no free water in the surface layers, preferably at the end of the accumulation season. The heat content of the glacier is then at a minimum.

\section{Crevasses}

Water flowing into crevasses which penetrate the $z_{0}$ surface has zero energy content by our definition and therefore $Q_{\mathrm{A}}$ is not changed. However, the corresponding mass, $M_{\mathrm{A}}$, is changed and an error is introduced into the calculation of change of mass of the glacier.

\section{Temperate glaciers}

A simplification of Equation (3) is possible for temperate glaciers. The temperature of the whole ice mass is very close to the melting point at the end of the ablation season.

$$
c \iiint_{V} \rho \theta \mathrm{d} V
$$


is therefore zero and

and

$$
E=L \iiint_{V} \rho \mathrm{d} V=L M
$$

$$
\Delta E=L \Delta M
$$

Changes in energy are due solely to the latent heat associated with changes in mass of ice.

\section{Other ice masses}

Although we have discussed a valley glacier the same considerations may be applied to some other ice masses. The method cannot be applied to ice shelves because of the practical difficulties in determining the energy exchange beneath them.

A simple and probably fruitful extension is to large ice sheets (Fig. 3a). No ice flows into a sector bounded by the ice divide and two flow lines (Fig. 3 b). The analysis for this volume exactly corresponds with that for the valley glacier.

a)
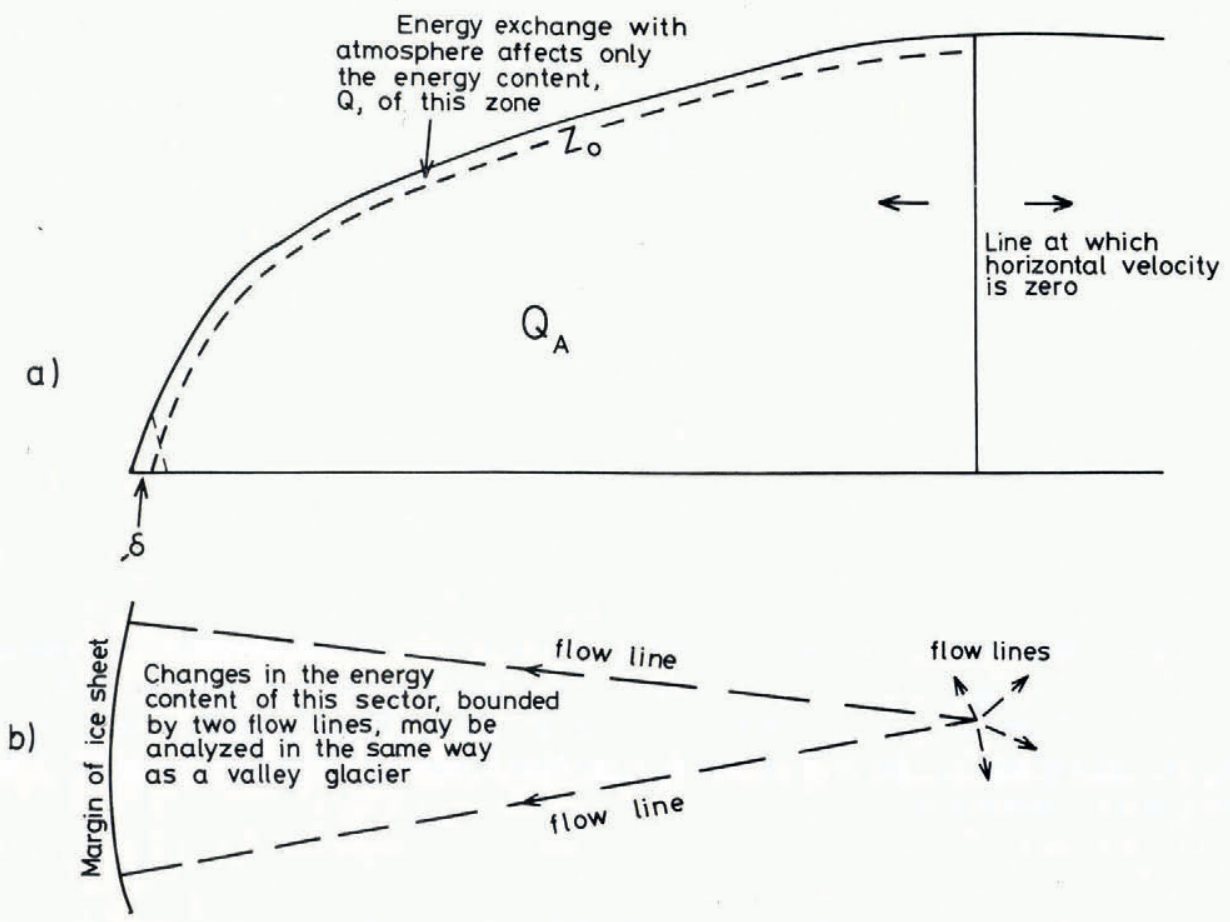

Fig. 3. Cross-section of an ice sheet showing zones corresponding to those in a valley glacier.

\section{Conclusions}

In the past, emphasis has been laid on determining the components of the energy exchange. These are difficult to measure accurately over sufficiently long periods to give useful information about the long-term behaviour of the glacier. We believe that direct methods should be used to determine accurately changes in the energy and mass of glaciers. Only then should attempts be made to relate these changes to meteorological parameters.

MS. received 17 November 1975 and in revised form 6 April 1976 


\section{REFERENCES}

Dalrymple, P. C., and others. 1966. South Pole micrometeorology program: data analysis, by P. C. Dalrymple, H. H. Lettau and S. H. Wollaston. (In Rubin, M. J., ed. Studies in Antartic meteorology. Washington, D.C., American Geophysical Union, p. 15-58. (Antarctic Research Series, Vol. 9.)

Deacon, E. L. 1949. Vertical diffusion in the lowest layers of the atmosphere. Quarterly Fournal of the Royal Meteorological Society, Vol. 75, No. 323, p. 89-103.

Dudnik, E. E. 1971. Symap. Chicago, College of Architecture and Art, University of Illinois at Chicago Circle. (Dept. of Architecture and Art Report No. 7 1-1.)

Holmgren, B. 197I. Climate and energy exchange on a sub-polar ice cap in summer. Arctic Institute of North America Devon Island Expedition, 1961-1963. Part C. On the katabatic winds over the north-west slope of the ice cap. Variations of the surface roughness. Meddelanden från Uppsala Universitets Meteorologiska Institution, Nr. 109 .

Jamieson, A. W., and Wager, A. C. In press. Ice, water and energy balance at Spartan Glacier, Alexander Island. British Antarctic Survey Bulletin.

Liljequist, G. H. 1957. Enèrgy exchange of an Antarctic snow-field. Surface inversions and turbulent heat transfer (Maudheim, $71^{\circ} \mathrm{o}^{\prime} \mathrm{S}, 10^{\circ} 5^{\prime} \mathrm{W}$ ). Norwegian-British-Swedish Antarctic Expedition, 1949-52. Scientific Results, Vol. 2, Pt. ID.

Runcorn, S. K., ed. 1967. International dictionary of geophysics. Oxford, Pergamon Press.

Smith, J. L., and others. 1965. Measurement of snowpack profiles with radioactive isotopes, by J. L. Smith, W. W. Donald and M. S. Owens. Weatherwise, Vol. 18, No. 6, p. 247-88.

UNESCO/IASH. 1970. Combined heat, ice and water balances at selected glacier basins: a guide for compilation and assemblage of data for glacier mass balance measurements. Paris, UNESCO/IASH. (Technical Papers in Hydrology, 5.)

UNESCO/IASH. 1973. Combined heat, ice and water balances at selected glacier basins. Pt. II: specifications, standards and data exchange. Paris, UNESCO/IASH. (Technical Papers in Hydrology, 5, Pt. II.)

Wager, A. C. In press. Mapping the depth of a valley glacier by radio-echo sounding. British Antarctic Survey Bulletin. 